\title{
How Circadian Rhythms do Affect Anesthesiology and Research
}

\author{
Eckle T \\ Editorial \\ Associate Professor of Anesthesiology, Cardiology and Cell Biology, Department of Anesthesiology, University of Colorado Denver, USA.
}

\section{*Corresponding Author:}

Tobias Eckle, M.D., Ph.D.

Associate Professor of Anesthesiology, Cardiology and Cell Biology, Department of Anesthesiology, University of Colorado Denver, 12700 E 19th Avenue, Mailstop B112, RC 2, Room 7121, Aurora, CO 80045, USA.

Tel: +1-303-724-2932/2947

Fax: +1-303-724-2852

E-mail: tobias.eckle@ucdenver.edu

Received: May 27, 2015

Published: June 01, 2015

Citation: Eckle T (2015) How Circadian Rhythms do Affect Anesthesiology and Research. Int J Anesth Res. 3(1e), 1-2. doi: http://dx.doi. org $/ 10.19070 / 2332-2780-150001 \mathrm{e}$

Copyright: Eckle $\mathbf{T}^{\circ}$ 2015. This is an open-access article distributed under the terms of the Creative Commons Attribution License, which permits unrestricted use, distribution and reproduction in any medium, provided the original author and source are credited.

Two Billion Years ago the earth encountered two major changes: Sunlight and oxygen. Therefore, all organisms developed mechanisms to sense oxygen or light $[1,2]$. While sensing oxygen seems very important for health and well-being, the sensing of light and its impact on health is not well understood yet. In fact, oxygen probes help physicians and anesthesiologists to monitor the oxygen content in our patient's blood. If those levels are low we would immediately treat those conditions. However, light seems less appreciated even though both systems share many similarities - at least on a molecular level.

For oxygen we have a transcription factor named 'hypoxia inducible factor 1' which is a well-known adaptive mechanisms to correct conditions of low oxygen availability [3]. E.g. if oxygen levels drop and HIF1 becomes active genes such as VEGF are activated and help the body to build up new vessels to improve tissue perfusion and thereby oxygen levels [4].

For light we have the circadian rhythm proteins as light and in particular the switch between light and darkness has led to the development of a circadian system in all living organisms [2]. The key proteins of the circadian system are named Clock, Cryptochrome or Period and belong to the same protein family as HIF1A. It is a so-called superfamily of PAS domain positive proteins [2]. In fact, the PAS domain has been shown to sense light or oxygen [5].

However, while both systems seem equally important from an evolutionary stand point, it is not clinical practice yet to moni- tor light. Interestingly, there is rising evidence for a high impact of light and the light dependent circadian rhythms for health and disease. E.g. disrupted circadian rhythms are associated with metabolic disorders [6-9]. Light at night can increase triglyceride levels and increase body fat [10]. Sleep deprivation leads to insulin resistance and diabetes [6]. In fact many diseases show a circadian pattern $[1,2,11]$. As such, the occurrence of heart attacks or strokes are linked to certain time points during the day [11].

Everyday medication have different effects during a $24 \mathrm{~h}$ time period [12]. The one hundred top selling drugs have circadian targets and therefore blood pressure medications are more effective when taken in the evening $[12,13]$. The effects of anesthetics such as neuromuscular blocking agents [14] or local anesthetics [15] or even outcome from anesthesia [16] have been shown to be linked to the circadian system. In fact, the high amount of cycling proteins and physiological functions in our human body rises the question if anesthesia or research might have different outcomes if performed at different time points. Even though it seems logical, no clinical or research study seems to address the impact of circadian rhythms on outcome or results. In a clinical setting we try to be efficient and even have centers where surgeries are performed $24 / 7$. In research, nobody knows if the experiments were conducted in the morning or late at night. Many findings and in particular negative findings could be a result of such an inaccuracy. Hopefully future clinical and basic science studies in anesthesiology and beyond will control for those factors. In fact, many studies might need to be repeated in light of this important but disregarded system: the circadian rhythms, evolved over the last two billion years.

\section{References}

[1]. Brainard J, Gobel M, Bartels K, Scott B, Koeppen M, et al., ( 2014) Circadian Rhythms in Anesthesia and Critical Care Medicine: Potential Importance of Circadian Disruptions. Semin Cardiothorac Vasc Anesth 19(1): 49-60.

[2]. Brainard J, Gobel M, Scott B, Koeppen M, Eckle T (2015) Health Implications of Disrupted Circadian Rhythms and the Potential for Daylight as Therapy. Anesthesiology 122(5): 1170-5.

[3]. Eltzschig HK, Carmeliet P (2011) Hypoxia and inflammation. New England Journal of Medicine, 364(7), 656-665.

[4]. Eltzschig HK, Eckle T (2011) Ischemia and reperfusion--from mechanism to translation. Nat Med 17(11): 1391-1401.

[5]. Taylor BL, Zhulin IB ( 1999) PAS domains: internal sensors of oxygen, redox potential, and light. MicrobiolMolBiol Rev 63(2): 479-506.

[6]. Depner CM, Stothard ER, Wright Jr, KP (2014) Metabolic consequences of sleep and circadian disorders. Curr Diab Rep 14(7): 5-7.

[7]. Staels B (2006) When the Clock stops ticking, metabolic syndrome explodes. Nat Med 12(1): 54-55.

[8]. Turek FW, Joshu C, Kohsaka A, Lin E, Ivanova G, et al.,(2005) Obesity and metabolic syndrome in circadian Clock mutant mice. Science 308(5724): 1043-1045. 
[9]. Zhang J, Kaasik K, Blackburn MR, Lee CC (2006) Constant darkness is a circadian metabolic signal in mammals. Nature 439(7074): 340-343.

[10]. Obayashi K, Saeki K, Iwamoto J, Okamoto N, Tomioka K, et al.,(2013) Exposure to light at night, nocturnal urinary melatonin excretion, and obesity/ dyslipidemia in the elderly: a cross-sectional analysis of the HEIJO-KYO study. J ClinEndocrinolMetab 98(1): 337-344.

[11]. Bonney S, Hughes K, Harter PN, Mittelbronn M, Walker L, et al.,(2013) Cardiac period 2 in myocardial ischemia: clinical implications of a light dependent protein. Int J Biochem Cell Biol 45(3): 667-671.

[12]. Zhang R, Lahens NF, Ballance HI, Hughes ME, Hogenesch JB (2014) A circadian gene expression atlas in mammals: implications for biology and medicine. Proc Natl AcadSci U S A 111(45): 16219-16224.
[13]. Hermida RC, Ayala DE, Smolensky MH, Mojon A, Fernandez JR, etal.,(2013) Chronotherapy improves blood pressure control and reduces vascular risk in CKD. Nat Rev Nephrol 9(6): 358-368.

[14]. Cheeseman JF, Merry AF, Pawley MD, de Souza RL, Warman GR (2007) The effect of time of day on the duration of neuromuscular blockade elicited by rocuronium. Anaesthesia 62(11): 1114-1120.

[15]. Vieira WS, Hidalgo MP, Torres Ida S, Caumo W (2010) Biological rhythms of spinal-epidural labor analgesia. ChronobiolInt 27(4): 865-878.

[16]. Rasmussen LS, O'Brien JT, Silverstein JH, Johnson TW, Siersma VD, et al.,(2005) Is peri-operative cortisol secretion related to post-operative cognitive dysfunction? ActaAnaesthesiolScand 49(9): 1225-1231. 